\title{
SOCIO-ECONOMIC FACTORS, CONJUGAL RELATIONS AND CONTRACEPTIVE USE IN URBAN SOUTH-WEST NIGERIA
}

\section{Stella O. BABALOLA}

\section{Introduction}

The relationship between contraceptive use and fertility has been well documented in demographic and related literature. Since Davis and Blake identified this factor as one of the intermediate determinants of fertility, many studies based on aggregate and individual-level data have confirmed the prominent role played by contraception in determining the level of fertility. Indeed, it is through contraception that an increasing number of women all over the world are achieving the desired interval between births and successfully limiting the number of their offspring.

Nonetheless, in Africa, contraceptive use has yet to extend to every part of the society. The results of the recent Demographic and Health Surveys (DHS) in many countries have revealed that prevalence rates as low as 5 per cent are common place. A typical example is Nigeria where, according to the findings of the 1990 DHS only 6 per cent of married women of reproductive age were currently using contraception (FOS/DHS, 1991).

Moreover, while it is true that prevalence rates are generally higher in urban than in rural areas, the former are sometimes worse off in terms of fertility reduction. This is easy to understand. In the rural area traditional and efficient child spacing methods such as prolonged breastfeeding and extended post-partum abstinence are still widely practiced. In the urban area on the other hand, the traditional methods are gradually being abandoned and are not effectively replaced by modern contraception. The consequence is that in some African societies urban fertility could be as high or even higher than rural fertility (e.g. Babalola, 1992). The question of what factors influence the adoption of contraception in an urban setting is therefore of prime importance for policy and programmatic issues. 
That conjugal relations have a bearing on the other aspects of a woman's life in particular and on the well-being of the family in general cannot be disputed. Indeed, such aspects of conjugal relations as the decision making process, financial management, and the division of labor can be expected to influence the woman's non-wife roles and have far-reaching effects on the lives of other members of the nuclear and extended families.

Empirical and theoretical evidence abounds in demographic literature to the effect that there exists an association between conjugal relations and the ultimate family size. There is also enough evidence to demonstrate a relationship between conjugal relations and the direct determinants of fertility. Moreover, all major social psychological theories (social exchange, equity, and field theories) predict a strong influence for conjugal relations in the marital decision making process.

Reflecting on the situation in Latin America, Bravo (1989) noted that "women's situation as defined by cultural factors which are present both in the sexual division of labor and in power relationships ... [have] consequences which are reflected in their reproductive behavior." In his study of Los Angeles, Bardsley (1983) found that conjugal power influences fertility through marital satisfaction. His findings reveal that the woman's conjugal power is one of the strongest predictors of pregnancies and births. Also, examining the attitudes of Ghanaian single male students with regard to family size and conjugal norms to include husband dominance, influence of kin in decision making and segregation in conjugal role relationships, Oppong (1878) found smaller family norms to be associated with an egalitarian relationship in decision making and household task and performance. Similarly, Kar and Cumberland (1984) have identified conjugal power as one of the key determinants of contraceptive use in countries as culturally diverse as Kenya, Venezuela, and the Philippines.

Back (1973) reviewed the existing literature on the relationship between family structure and fertility control. He contended that empirical evidence concerning the relationship between family structure and fertility is not unidirectional. The studies he reviewed revealed contradictory evidence with respect to the association between aspects of familial interaction (such as husband-wife dominance and conjugal 
role relationships) and fertility. He also suggested that family structure (i.e. either nuclear or consanguineous) alone cannot be taken as a main determinant of fertility patterns. According to him, affection appears to be the intervening variable between marital conditions and fertility.

A study of family structure and fertility in India tends to lend credence to the negative association between conjugal relationships and fertility (Desai, 1974). The study reveals that women who have joint conjugal roles desire, on the average, smaller families than those who exhibit segregated role relationships. The study further reveals that the number of children expected increased as conjugal role segregation increases. Similarly, in a study of junior and intermediate level workers in Ghana, Oppong (1977) found that the desire for a small family is associated with joint decision making.

In the light of the existing literature, the aim of the present paper is to examine the effects of some aspects of conjugal interaction on contraceptive use in a Nigerian urban setting. The conjugal relations which we shall consider include financial management, intimacy between spouses, and decision making process.

\section{Data and Methods}

The data employed in the present analysis derive from a 1989 survey of the proximate determinants of fertility in southwestern Nigeria. The survey was conducted in Ibadan and in a number of rural locations in Oyo State. The survey questionnaire contained a household form and sections on the socio-economic characteristics of the respondents, marital history, reproductive history, fertility preferences, proximate fertility variables, conjugal relationship and domestic organization of the home. A total of 1552 women (781 from Ibadan and 771 from the rural locations) were successfully interviewed. The data presented in this paper pertain to the urban segment of the study. A detailed description of the sampling method has been provided elsewhere (Babalola, 1992).

Ibadan, the capital of Oyo State, is located some 120 kilometers to the northwest of Lagos. The city, with a population of about 1 million, is the seat of the oldest university in Nigeria. 
Both bivariate analysis and multivariate analysis will be used in this paper: On the whole, the aim will be to highlight the gross and net effects of a number of socio-economic and conjugal factors on contraceptive use. In the cases of conjugal decision making process and intimacy between spouses which are analyzed as scores, ordinary least squares will be used to estimate the net effects of the independent variables. On the other hand, for financial management and contraceptive use, which are analyzed as indicator variables, the appropriate multivariate analytic procedure is logistic regression. The analytic framework is based on the assumption that socio-economic factors influence contraceptive use through their effects on conjugal relations. We do recognize that there are some important non-conjugal factors (such as knowledge, attitudes and access to contraception) which influence contraceptive practice. However the discussion of such factors is beyond the scope of the present paper.

Against the background of the adopted conceptual framework, we shall, in the first instance, examine the level and socio-economic variations in contraceptive use in the city. Subsequently, we shall discuss the effects of socio-economic variables on conjugal relations. Thirdly, we shall examine the effect of conjugal relations on contraceptive use. Finally, by way of conclusion, the policy and programmatic implications of the findings will be discussed.

\section{Socio-Economic Correlates of Contraceptive Use}

The level of contraceptive usage is relatively quite high in Ibadan. Almost half the women interviewed (47.6\%) were using one modern contraceptive method or the other while another 12 per cent were using natural or traditional methods. These figures show that contraceptive use in the city of Ibadan is exceptionally high by Nigerian standards. Indeed, according to the 1990 Demographic and Health Survey (DHS) contraceptive prevalence is 10.5 per cent in Southwest Nigeria (modern methods).

In terms of methods used, the IUD and the pill are, in that order, by far the most popular methods. About 30 per cent of all the women interviewed or 64 per cent of all contracepting women were using either of these methods. The injectable, a method relatively easy 
to use only comes third. This pattern is somewhat consistent with the findings on the Nigeria DHS (FOS, 1992) and similar to that observed recently among family planning users in Lagos State (Population Council, 1992). It is interesting to note that about 9 per cent of the respondents were practising natural family planning which includes abstinence, withdrawal, and the calendar method.

There are important socio-economic variations in contraceptive use among the respondents, as can be seen from Table 2. The woman's education appears to be positively correlated with contraceptive use. Whereas only about 30 per cent of the women without any formal education were currently contracepting, as many as half of those with secondary education or higher were using contraceptives. Moreover the differences between the educational groups are significant at the 0.001 level. Christians (52\%) are significantly more likely to practice contraception than Moslems (34\%), and monogamously married women (53\%) more likely than their polygynously married ones (36\%). Age appears to have a rather curvilinear relationship with contraception. The women at the extreme child-bearing age groups (less than 25 years and more than 45 years) are the ones least likely to contracept whereas those most likely to use contraception are those within the 35-49 age group. Parity, for its part, appears to have significant positive effects on contraception: only 36 per cent of the women with two children or fewer compared with about 55 per cent of those who had between six and eight children were contracepting. Likewise, as expected, the higher the husband's education, the more likely the woman is to contracept. Indeed the proportion currently contracepting increases monotonically from 30 per cent among the women whose husbands have no formal education to 51 per cent among those whose husbands have post-secondary education.

The results of the logic regression of contraceptive use on some socio-economic variables are presented in Table 3 . The independent variables included in the estimated model and in subsequent ones are as follows:

education: introduced as a dummy variable which is equal to 1 if woman's education is secondary or more, and 0 if less than secondary; 


\section{- $\quad$ religion: dummy variable which equals 1 if Christian and 0 if Moslem; \\ - marriage type: dummy variable which equals 1 if union is monogamous and 0 if polygynous; \\ - working status: dummy variable which equals 1 if woman economically active and 0 if not; \\ - parity: introduced as an interval scale variable; and, \\ - $\quad$ age: introduced as an interval scale variable.}

Before going on to examine the relationship between the socioeconomic variables and contraceptive use, it will be worthwhile to examine the correlations among the various independent variables.

The correlation matrix does not indicate any large amount of collinearity among the explanatory variables. Actually, most of the independent variables are relatively unrelated to one another. The variables with the highest correlation coefficient are age and children ever born. However, the two variables are not sufficiently interrelated to warrant the exclusion of either of them from the estimated model. In sum we feel that the independent variables retained should enable us to explain as much variation in contraceptive use as possible.

The logic regression enables us to appreciate the net effects of each of the independent variables. It confirms the findings of the bivariate analysis. For example, post-primary education and Christianity have positive independent effects on contraceptive use. Likewise monogamous union and increasing age and parity appear to enhance the chances of contraception. On the other hand, whether a woman works or not does not seem to have any significant effect on her probability of contracepting. The regression further shows that the socio-economic factors which influence contraceptive use most are parity, Christianity, monogamous union, and secondary education.

In sum, contraceptive use level differs among socio-economic groups. Albeit, we believe that socio-economic variables per se do not influence contraceptive use directly but operate by modifying some proximate determinants of contraception such as conjugal relations. In the next section we shall examine the effects of socio-economic variables on some indicators of conjugal relations. 


\section{Socio-Economic Characteristics and Conjugal Relations}

In this section, we shall examine three indicators of conjugal relations: financial management, intimacy between spouses, and conjugal decision making process. As previously stated, the aim is to highlight the relationships between these indicators and some socioeconomic variables against the background that the latter influence contraceptive behavior by modifying the former.

Financial management: The type of financial organization practiced by a couple is an indication of how modern or otherwise the couple is in their relationship with each other. It is traditional in the Yoruba society for husband and wife to keep separate accounts with each knowing little or nothing about the other's finances. On the other hand, joint financial management is a feature of modern western society.

Most of the women interviewed (86\%) stated that they practised segregation of resources with their husbands while only 14 per cent appeared to pool financial resources with their spouses.

The prevalence of joint ownership of accounts varies appreciably with socio-economic characteristics (see table 4). For example, when the woman has post-secondary education, the chances that the couple own a joint account $(18.7 \%)$ is almost thrice as much as if she has no formal education (6.7\%). Also, Christian couples appear twice as likely to pool their resources than do Moslems. The age of the woman and the age difference between spouses do not appear to have any clear-cut effects on the practise of joint ownership of financial resources. Albeit, women aged less than 25 years and those aged between 5 and 9 years less than their husbands are more likely than others to own a joint account.

Nevertheless, as can be seen from Table 6, socio-economic variables actually play only a limited role in determining the type of financial organization existing between spouses. Indeed, after controlling for interrelationships between the independent variables in a multivariate model, the only factor which appears to have any significant effect on the dependent variable is type of marriage. 
Monogamously married couples are significantly more likely to pool financial resources than are their polygynous counterparts.

On the whole, it appears that although there are some socioeconomic differences in the prevalence of the practice of joint ownership of accounts between spouses, there are more important factors cutting across socio-economic groups which determine whether or not a couple will decide to own a joint account. This is not surprising since joint ownership of an account is based on mutual trust between the spouses, a factor which, to some extent, is independent of socio-economic status.

Intimacy Between Spouses: It can be argued that to the extent that spouses are close in terms of doing things together, the decision to adopt modern contraception and continue its use will be easier to sustain. The respondents were asked if they and their husbands usually engage in a number of intimate and social activities jointly. The activities referred to include: sleeping on the same bed, eating together, visiting friends and relatives together, discussing health problems, discussing work-related problems, and sharing secrets. It is obvious that the extent to which these activities are done jointly reflect the degree of intimacy between the spouses. The respondents were scored on the basis of their responses to the six questions - they were simply scored 1 if they answered "yes" or 0 if they answer is "no". The points obtained by each respondent were then summed to obtain a composite score ranging between 0 and 6 . The respondents were further divided into three categories - low, medium and high degrees of intimacy - depending on their scores.

Generally speaking, respondents appear to be close to their spouses. Very few couples (7.5\%) demonstrate a low level of intimacy (composite score of two or less), whereas many (62.5\%) exhibit a high intimacy level (composite score of five or more). It is interesting to note that the degree of intimacy varies considerably with socioeconomic groups (Table 7). The level of intimacy between spouses increases with education. Almost 80 per cent of women with postsecondary education manifest a high degree of intimacy in their relationships with their spouses, compared to about 27 per cent of the women with no education. Likewise 67 per cent of women whose 
husbands have secondary education or more compared with less than 40 per cent of those whose husbands have primary education or less, enjoy a high degree of conjugal intimacy. Christian couples are more likely than their Moslem counterparts to exhibit intimate conjugal relationships. Rather unexpectedly neither age nor age difference between spouses appear to have any appreciable effect on conjugal intimacy. It is however worthwhile to mention that the women aged less than 25 years appear to enjoy more intimate conjugal relations than others.

The results of the regression analysis which estimates the "pure" effects on intimacy score of wife's education, current age, employment status, marriage type, religion and age difference between spouses confirm some of the findings of the preceding bivariate analysis. Conjugal intimacy appears considerably more sensitive to socioeconomic characteristics than the type of conjugal financial organization. About 21 per cent of the variation in conjugal intimacy is attributable to differences in socio-economic characteristics. Moreover, the wife's characteristics such as education, monogamous union, age and working status have positive and very significant effects on the level of intimacy between spouses. On the other hand, rather unexpectedly, the effects of religion and age gap between spouses are not significant (Table 8).

Decision Making Pattern: The survey included questions on how the couple usually reach a decision concerning some household matters. The household decisions covered in the present analysis concern:

where to live, the number of children to have, which school children should attend, whether to use contraceptive, and, buying household equipment.

The questions were intended to elicit the decision making process and determine the wife's conjugal power. The respondents were given a score ranging from 0 to 4 on each question depending on their response. The alternative responses to each question are: husband decides alone ( 0 ), either of the spouses decides alone (2), both discuss 
then decide (3), and wife decides alone (4). A composite score was then computed for each respondent based on the scores on the individual questions. Generally, the higher the composite score the less husband-dominated and the more egalitarian the decision making process is. To facilitate the analysis, respondents were divided into four categories on the basis of their composite scores. A detailed examination of the decision making pattern of the respondents in each of the four categories allowed us to designate the categories as follows:

Autocratic: conjugal decision making is essentially husband-dominated;

Incipient democracy: the wife participates only in a few of the important household decisions;

Transitional: only a few of the household decisions are taken by the husband alone; and,

Egalitarian: most if not all the important household decisions are taken by the couple after deliberation.

The analysis of the decision making process which follows will, in the first instance, be based on the above four categories. Subsequently, we shall examine the socio-economic correlates of the decision making score using a multi-variate model.

Many of the respondents are in the transitional $(36.7 \%)$ or the egalitarian (27.8\%) decision making categories. It is however interesting to note that as many as 12 per cent of the women have autocratic husbands while for some 23.5 per cent conjugal "democracy" is still incipient. Moreover, some variations can be observed in the decision making patterns of the different socio-economic groups (see Table 9). For example, the autocratic decision making pattern recedes while the egalitarian pattern become more prominent as the woman's level of education increases. A similar tendency is observed with the husband's education. Not only this, but the differences in the decision making patterns of the educational groups appear very significant. There are also significant differences among Christians and Moslems: whereas about 31 per cent of Christians enjoy egalitarian conjugal decision making, only 17.5 per cent of Moslems do. Likewise, as 
expected, conjugal decision making process is likely to favor the woman if she is employed more than if she is a full time housewife. Furthermore, the woman's conjugal power appears to decrease if she is ten years or more younger than her husband. On the other hand, the woman's age does not appear to have any appreciable influence on decision making although women aged 45 years and above tend to exercise more conjugal power than their younger counterparts.

In order to identify the net effects of each of the socio-economic variables, we have again controlled for their effects simultaneously in a multivariate model. The results are presented in Table 10. It can be seen from the value of the explained variance (about 6\%) that socioeconomic variables are only marginally important in determining the position of the woman in conjugal decision making. Nonetheless, the results show that the variables which have the most sustained and significant effects on conjugal decision making are the woman's education, her current age, and the age gap between spouses. As the woman's education increases from primary or less to secondary and above, the decision making score increases by about 1.4 points. The age gap between spouses, for its part, appears to have a negative effect on the woman's conjugal power. An increase of one year in the age difference between spouses is associated with a decrease of 0.07 point in the wife's decision making score. The regression results further show that the observed differences between working and non-working women, on the other hand, are mostly due to the interactions of these variables with the other socio-economic variables included in the model. Indeed, the woman's employment status or her religion do not appear to have any significant independent effects on conjugal power sharing.

To summarize, we have found that conjugal relations tend to vary with socio-economic characteristics. Of the three indicators of conjugal relations considered, the least sensitive to socio-economic variables appears to be conjugal financial organization. On the other hand, the indicator that responds most to changes in socio-economic characteristics appears to be the degree of intimacy between spouses. Additionally, the most outstanding socio-economic correlate of conjugal relations appears to be education. This variable was found to be a significant determinant of each of the three indicators of conjugal 
relations. Other important determinants are religion and age gap between spouses. The policy and programmatic implications of these findings will be discussed later. Meanwhile we shall examine the relationship between conjugal relations and contraceptive use.

\section{Conjugal Relations and Contraceptive Use}

In this section we shall examine how the three indicators of conjugal relations influence contraceptive use. Firstly, we shall discuss differences in the level of contraceptive use by type of conjugal relations. Secondly we shall identify the independent effects of the three indicators of conjugal relations on contraceptive use. The three indicators could be seen in Table 3 to exhibit relatively low levels of collinearity.

As expected, contraceptive use varies with pattern of conjugal relations. If we take the type of conjugal financial relationship for example, contraceptive use is more prevalent among those women who practice joint ownership of accounts than among the others. Note however, that the differences among the two categories are hardly statistically significant. The level of intimacy between couples appears to be strongly correlated with contraceptive use. Generally speaking, the more intimate the couple is, the more likely they are to use a modern contraceptive method. Thus the proportion contracepting increases from about a quarter among the women with low intimacy score to more than half among those exhibiting a high level of intimacy. In the same manner, contraceptive use varies with conjugal decision making pattern. Not surprisingly, the more egalitarian the decision making process the more likely the couple is to practice contraception. By way of example, whereas only 36.8 per cent of the women with autocratic husbands use modern contraception, some 53 per cent of those manifesting an egalitarian decision making pattern do.

The results of the logistic regression analysis contained in Table 12 confirms that the three indicators of conjugal relations - "jointness" in financial matters, conjugal power of the wife and intimacy between spouses all play some role in determining the chances of using modern contraception. More importantly, the regression results show that the level of intimacy between spouses is the most important aspect of 
conjugal relations in terms of effects on contraceptive use. According to the results, the logic of contracepting, $\ln [\mathrm{px} / 1-\mathrm{px}]$, increases by about 0.16 as intimacy score increases by one.

In sum, there are differences in contraceptive use by patterns of conjugal relations. By and large, financial jointness as opposed to financial autonomy favors contraceptive use whereas husband dominated decision making patterns tend to be associated with decreased contraceptive use. Another interesting finding is that the more intimate a couple is the more likely they are to contracept.

Thus far, we have been able to show that both socio-economic factors on the one hand, and conjugal relations on the other, have an influence on contraceptive use. The question now is what is the pattern of linkages among socio-economic factors, conjugal relations and contraceptive use? In other words, as hypothesized above, do socioeconomic variables affect contraceptive use through conjugal relations?

Table 13 shows the performance of socio-economic factors in the presence of conjugal factors. Model 1 on the Table looks at the effects of socio-economic factors on contraceptive use. Model 2 demonstrates the effects of the socio-economic factors net of the degree of intimacy between spouses, while Model 3 considers the effects of socio-economic variables net of all aspects of conjugal relations.

Some interesting findings emerge from the Table. Firstly, we observe that the inclusion of the type of financial management and decision making pattern in Model 3 does not appear to result in any significant gain in our ability to predict contraceptive use. Secondly, with the introduction of the measure of intimacy into the equation (Model 2) five of the six socio-economic variables - education, employment status, religion, current age and type of union - become less significant. Apparently, the effects of these five variables on contraceptive use are, to some significant extent, channelled through the level of intimacy between spouses. Thirdly, parity remains a very strong predictor of contraceptive use in the presence of conjugal relations factors. This indicates that this factor has significant net effects on contraceptive use which do not depend on the pattern of conjugal relations. Actually, the strong positive association between 
parity and contraceptive use indicates the use of contraception more for the purpose of stopping child bearing than for spacing. The information on Table 13 indicates that irrespective of the type of conjugal relation a woman experiences, once she attains a certain parity she resorts to contraception.

\section{Conclusion}

The foregoing has examined socio-economic variations in contraceptive use in Ibadan city using data from a 1989 survey. The analysis was done against the background assumption that socioeconomic variables do not influence contraceptive use directly but only through conjugal relations and other factors.

Contraceptive use was found to be very high in the city by Nigerian standards: some $47 \%$ of the women interviewed were using one modern contraceptive method or the other. Moreover, as expected, there are important socio-economic differences in contraceptive use. Indeed the women most likely to practice contraception are those of higher parity (above three children), and who are Christians, monogamously married and secondary educated. These same factors were found to favor intimacy between spouses and enhance the position of the woman in conjugal decision making. Special mention should however be made of education which appears to be the most important socio-economic determinant of conjugal relations. Regarding each of the three measures of conjugal relations considered (financial management, decision making process, and intimacy between spouses) women with secondary education or more are significantly better off than the others.

The analysis of the relationship between conjugal relations and contraceptive use reveals that the most important aspect of conjugal relations in this respect is the degree of intimacy between spouses. In fact, while there exist some expected differences in the level of contraceptive use by type of financial management and by pattern of conjugal decision making, the net effects of these variables are not significant. 
Finally, our findings tend to support the hypothesis that conjugal relations play an intermediary role between socio-economic variables and contraceptive use. Actually, we are able to show that socioeconomic characteristics are strongly correlated with contraceptive use and also with conjugal relations. Moreover, when the effects of both socio-economic and conjugal intimacy and other indicators of conjugal relations factors on contraception are estimated in the same model, most of the socio-economic variables tend to become less significant. This finding indicates that conjugal relations, in general, and the degree of intimacy between spouses, in particular, play an intermediary and more direct role in the relationship between certain socio-economic variables and contraceptive use. It is however very pertinent to note that parity has significant effects on contraception independent of conjugal relations.

These findings have important policy and programmatic implications. The main issue here is that conjugal relations, especially the degree of intimacy between spouses have a strong influence on contraceptive use. We can therefore hypothesize that by increasing the level of intimacy between couples and enhancing the position of the woman in conjugal decision making, we will ultimately increase contraceptive prevalence. However, it is not always easy to come up with an intervention that will directly modify conjugal relations. The solution lies mainly within the direct socio-economic determinants of conjugal relations. In other words, relevant programs should aim at influencing the socio-economic variables in the right direction with the ultimate objective of intensifying contraceptive use.

Special attention should continue to be paid to female education, not just to facilitate the acquisition of literacy for women but also to enable them attain high educational levels. Educated women are more likely to experience intimate conjugal relations and participate actively in conjugal decision making. These factors have been found to enhance contraceptive use. Efforts should be intensified to correct the perception of the role of the wife and enhance the general position of the woman within the society in general, and among Moslems, in particular. There is thus need for relevant information, education and communication activities specially designed for Moslems. The activities should aim at promoting a more intimate and egalitarian 
relationship between spouses. This could be done through Islamic organization and key Islamic opinion leaders. Finally, female employment and monogamous marriage, which enhance intimacy between spouses, should be promoted.

Table 1: Distribution of Respondents According to Contraceptive Method Currently Being Used

\begin{tabular}{|c|c|}
\cline { 2 - 2 } \multicolumn{1}{c|}{ Contraceptive method } & $\begin{array}{c}\text { Percent } \\
\text { using }\end{array}$ \\
\hline IUD & 19.2 \\
Pill & 11.1 \\
Injection & 6.7 \\
Condom & 6.3 \\
Spermicide & 3.6 \\
Natural & 8.6 \\
Traditional & 3.3 \\
None & 40.6 \\
\hline
\end{tabular}


Table 2: Proportion of Women Contracepting, by SocioEconomic Characteristics

\begin{tabular}{|l|c|c|c||}
\hline \multicolumn{1}{|c|}{ Socio-economic group } & $\begin{array}{c}\% \\
\text { Contra- } \\
\text { cepting }\end{array}$ & $\begin{array}{c}\text { Number } \\
\text { of } \\
\text { Women }\end{array}$ & $\begin{array}{c}\text { Chi }^{2} / \\
\text { Signifi- } \\
\text { cance }\end{array}$ \\
\hline Woman's education & 29.7 & 74 & $(0.001)$ \\
None & 41.5 & 142 & \\
Primary & 52.8 & 362 & \\
Secondary & 49.3 & 203 & \\
Post-secondary & & & $17.49 /$ \\
\hline Religion & 52.0 & 594 & $(0.000)$ \\
Christian & 34.1 & 173 & \\
Moslem & & & $7.85 /$ \\
Age group & 30.4 & 23 & $(0.165)$ \\
<25 years & 43.6 & 126 & \\
25-29 & 48.4 & 217 & \\
30-34-39 & 52.2 & 222 & \\
40-44 & 50.8 & 122 & \\
45+ & 39.1 & 64 & \\
\hline Parity & & & $18.178 /$ \\
<3 years & 36.3 & 201 & $(0.000)$ \\
3-5 & 50.9 & 450 & \\
6-8 & 54.5 & 99 & \\
\hline Marriage type & 85.7 & $(7)$ & \\
\hline Polygynous & & & $16.369 /$ \\
Monogamous & 35.6 & 177 & $(0.000)$ \\
\hline Husband's education & 53.0 & 562 & \\
\hline None & & & $10.918 /$ \\
Primary & 30.0 & 50 & $(0.012)$ \\
Secondary & 38.84 & 85 & \\
Post Secondary & 46.4 & 209 & \\
\hline
\end{tabular}




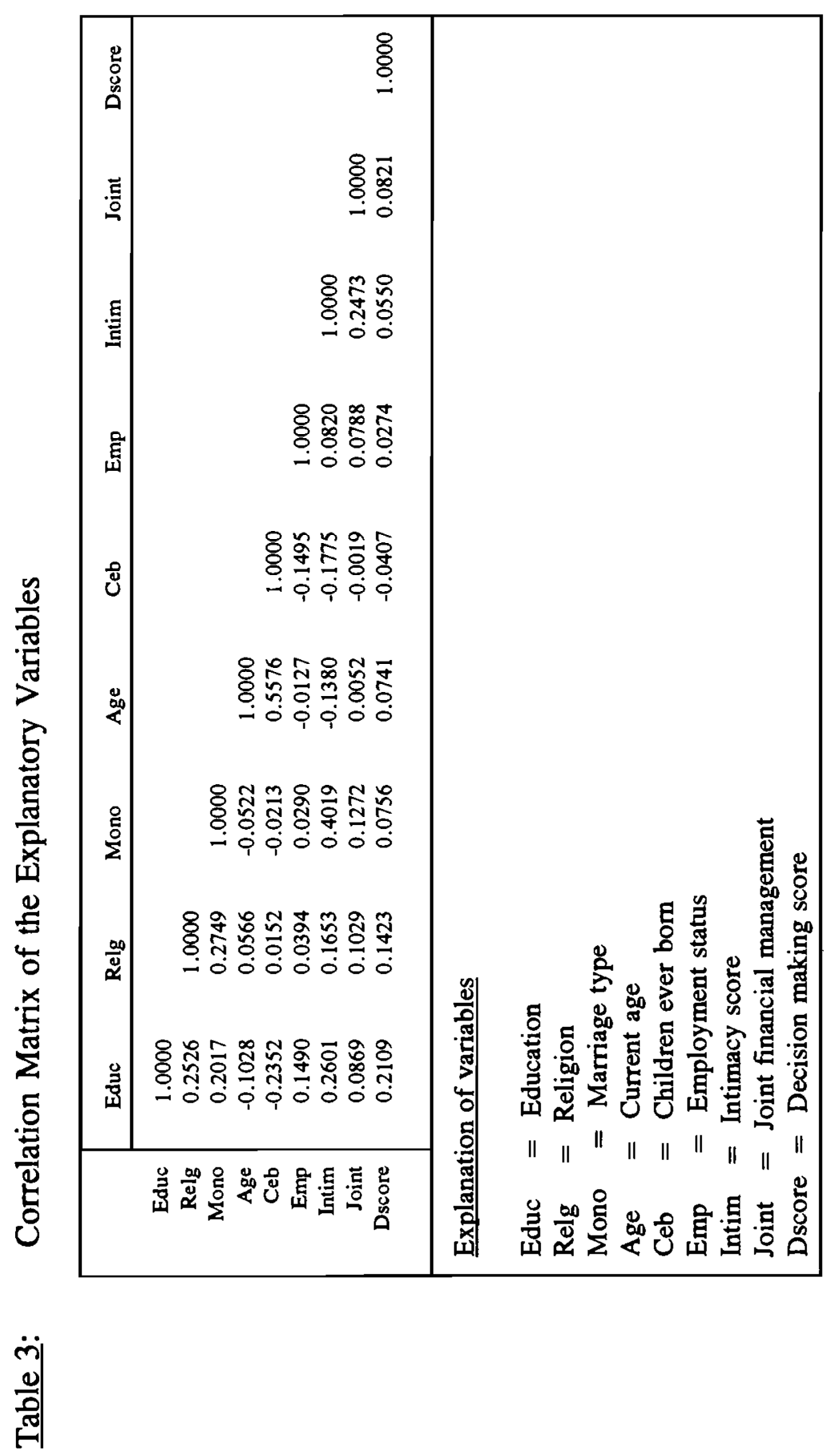




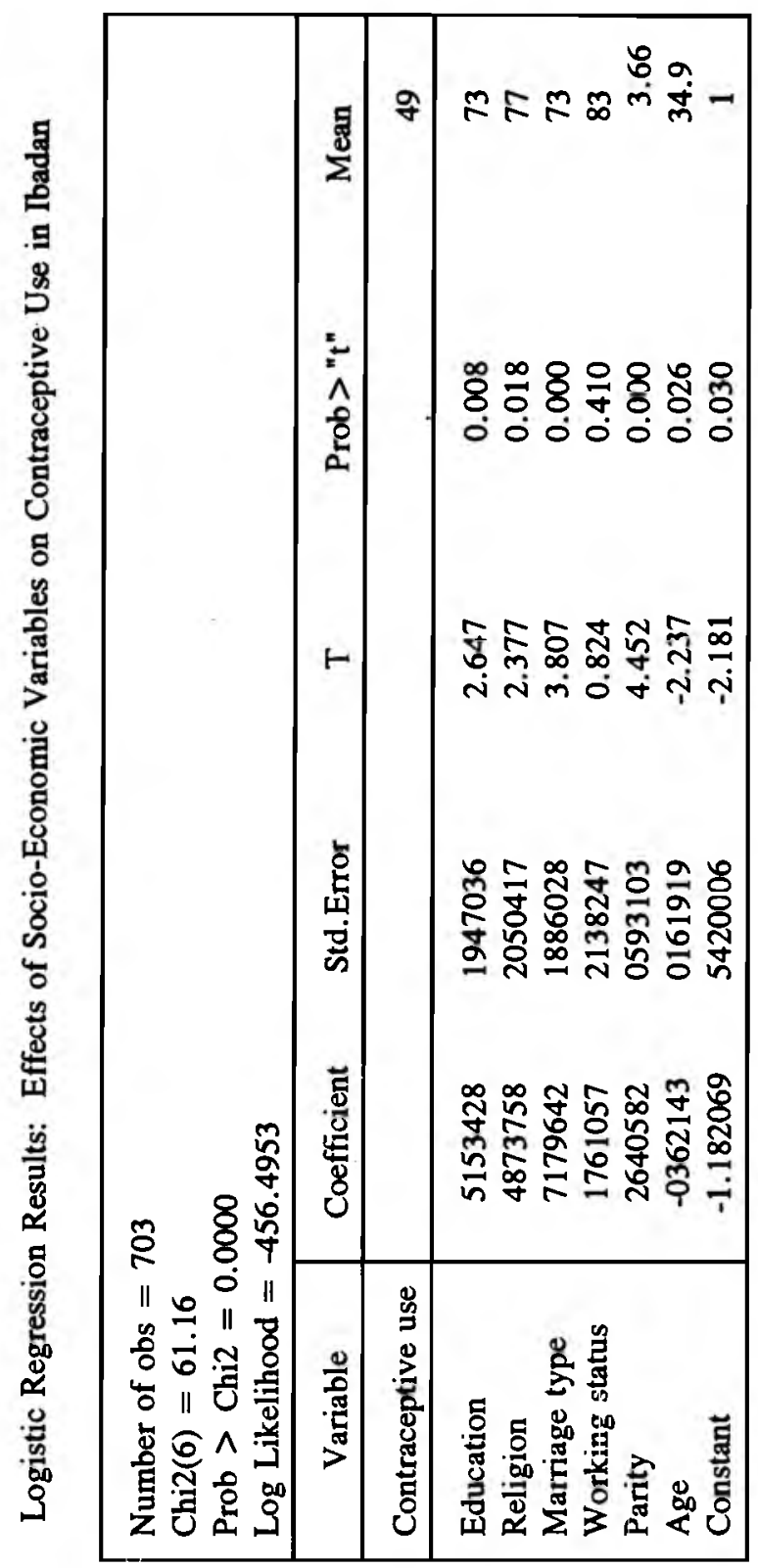

㻤 
Table 5: Prevalence of Joint Ownership of Accounts between Spouses, by Socio-Economic characteristics

\begin{tabular}{|c|c|c|c|}
\hline Socio-economic group & $\begin{array}{l}\text { Percent } \\
\text { owing } \\
\text { joint } \\
\text { account }\end{array}$ & $\begin{array}{c}\text { Number of } \\
\text { women }\end{array}$ & $\begin{array}{c}\mathrm{Chi}^{2} / \\
\text { Significance }\end{array}$ \\
\hline $\begin{array}{l}\text { Woman's education } \\
\text { None } \\
\text { Primary } \\
\text { Secondary } \\
\text { Post-secondary }\end{array}$ & $\begin{array}{r}6.7 \\
10.6 \\
14.4 \\
18.7\end{array}$ & $\begin{array}{r}74 \\
142 \\
362 \\
203\end{array}$ & $\begin{array}{l}8.36 / \\
0.039\end{array}$ \\
\hline $\begin{array}{l}\text { Religion } \\
\text { Christian } \\
\text { Moslem }\end{array}$ & $\begin{array}{r}16.0 \\
8.0\end{array}$ & $\begin{array}{l}594 \\
187\end{array}$ & $\begin{array}{l}7.46 / \\
0.006\end{array}$ \\
\hline $\begin{array}{l}\text { Employment status } \\
\text { Working } \\
\text { Not working }\end{array}$ & $\begin{array}{r}15.3 \\
8.3\end{array}$ & $\begin{array}{l}649 \\
132\end{array}$ & $\begin{array}{l}4.34 / \\
0.037\end{array}$ \\
\hline $\begin{array}{l}\frac{\text { Age group }}{<25 \text { years }} \\
25-34 \\
35-44 \\
45+\end{array}$ & $\begin{array}{l}21.7 \\
15.2 \\
11.3 \\
20.3\end{array}$ & $\begin{array}{r}23 \\
343 \\
344 \\
64\end{array}$ & $\begin{array}{l}5.63 / \\
0.131\end{array}$ \\
\hline $\begin{array}{l}\text { Age difference between spouses } \\
55 \text { years } \\
5-9 \text { years } \\
10+\end{array}$ & $\begin{array}{l}12.5 \\
16.2 \\
12.2\end{array}$ & $\begin{array}{l}239 \\
333 \\
172\end{array}$ & $\begin{array}{l}2.21 / \\
0.331\end{array}$ \\
\hline $\begin{array}{l}\text { Husband's education } \\
\text { Primary or less } \\
\text { Secondary or more }\end{array}$ & $\begin{array}{r}8.9 \\
15.0\end{array}$ & $\begin{array}{l}634 \\
135\end{array}$ & $\begin{array}{l}3.45 / \\
0.063\end{array}$ \\
\hline
\end{tabular}




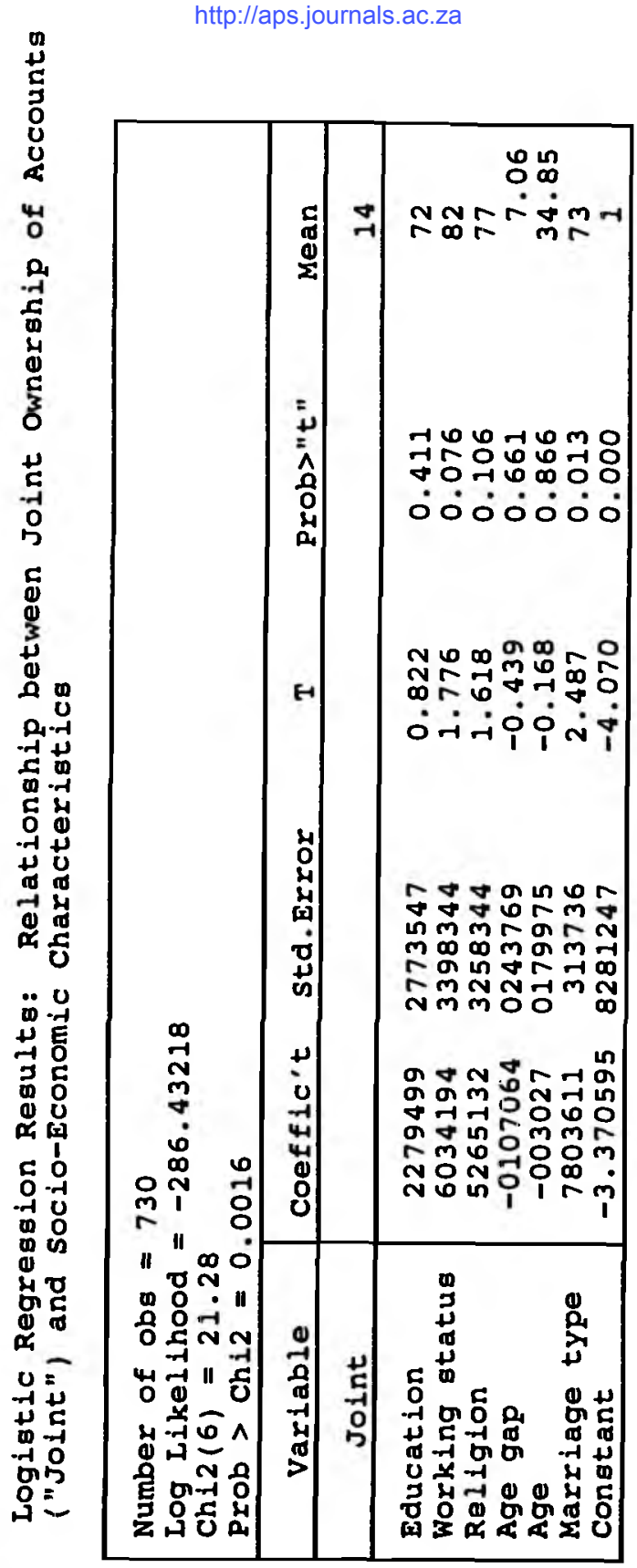

ㅊ. 
Table 7: Degree of Intimacy between Spouses, by SocioEconomic Characteristics

\begin{tabular}{|c|c|c|c|c|c|}
\hline \multirow[t]{2}{*}{ Socio-economic group } & \multicolumn{3}{|c|}{ Degree of intimacy } & \multirow{2}{*}{$\begin{array}{c}\text { Number } \\
\text { of } \\
\text { women }\end{array}$} & \multirow{2}{*}{$\begin{array}{c}\mathrm{Chi}^{2} / \\
\text { signifi- } \\
\text { cance }\end{array}$} \\
\hline & Low & Medium & High & & \\
\hline $\begin{array}{l}\text { Woman's education } \\
\text { None } \\
\text { Primary } \\
\text { Secondary } \\
\text { Post-secondary }\end{array}$ & $\begin{array}{r}19.4 \\
11.8 \\
5.0 \\
4.8 \\
\end{array}$ & $\begin{array}{l}53.7 \\
40.9 \\
28.5 \\
16.7 \\
\end{array}$ & $\begin{array}{l}26.9 \\
47.2 \\
66.6 \\
78.5\end{array}$ & $\begin{array}{r}67 \\
127 \\
323 \\
186 \\
\end{array}$ & $\begin{array}{r}75.98 / \\
0.000\end{array}$ \\
\hline $\begin{array}{l}\text { Reliaion } \\
\text { Christian } \\
\text { Moslem }\end{array}$ & $\begin{array}{r}6.2 \\
11.7 \\
\end{array}$ & $\begin{array}{l}25.2 \\
45.0 \\
\end{array}$ & $\begin{array}{l}68.4 \\
43.3 \\
\end{array}$ & $\begin{array}{l}534 \\
171 \\
\end{array}$ & $\begin{array}{l}35.4 / \\
0.000\end{array}$ \\
\hline $\begin{array}{l}\text { Emplovment statug } \\
\text { Working } \\
\text { Not working }\end{array}$ & $\begin{array}{r}6.9 \\
10.8 \\
\end{array}$ & $\begin{array}{l}28.0 \\
40.0 \\
\end{array}$ & $\begin{array}{r}65.1 \\
49.2 \\
\end{array}$ & $\begin{array}{l}583 \\
120 \\
\end{array}$ & $\begin{array}{r}10.97 / \\
0.004\end{array}$ \\
\hline $\begin{array}{l}\text { Aae aroup } \\
25 \text { years } \\
25-34 \\
35-44 \\
45+ \\
\end{array}$ & $\begin{array}{r}0.0 \\
6.1 \\
9.0 \\
11.1 \\
\end{array}$ & $\begin{array}{l}18.2 \\
28.1 \\
32.9 \\
25.9 \\
\end{array}$ & $\begin{array}{l}81.8 \\
65.8 \\
58.1 \\
63.0 \\
\end{array}$ & $\begin{array}{r}22 \\
310 \\
310 \\
34 \\
\end{array}$ & $\begin{array}{r}9.67 \\
0.139\end{array}$ \\
\hline $\begin{array}{l}\text { Age difference between } \\
\text { spouses } \\
<5 \text { years } \\
5-9 \text { years } \\
10+\end{array}$ & $\begin{array}{l}5.6 \\
8.3 \\
7.1\end{array}$ & $\begin{array}{l}32.6 \\
25.5 \\
36.4\end{array}$ & $\begin{array}{l}61.8 \\
66.2 \\
56.5\end{array}$ & $\begin{array}{l}215 \\
302 \\
154\end{array}$ & $\begin{array}{l}7.38 / \\
0.117\end{array}$ \\
\hline $\begin{array}{l}\text { Husband's education } \\
\text { Primary or less } \\
\text { Secondary or more }\end{array}$ & $\begin{array}{r}16.7 \\
5.4 \\
\end{array}$ & $\begin{array}{l}45.0 \\
27.2 \\
\end{array}$ & $\begin{array}{l}38.3 \\
67.4 \\
\end{array}$ & $\begin{array}{l}120 \\
573 \\
\end{array}$ & $\begin{array}{r}40.84 / \\
0.000\end{array}$ \\
\hline
\end{tabular}




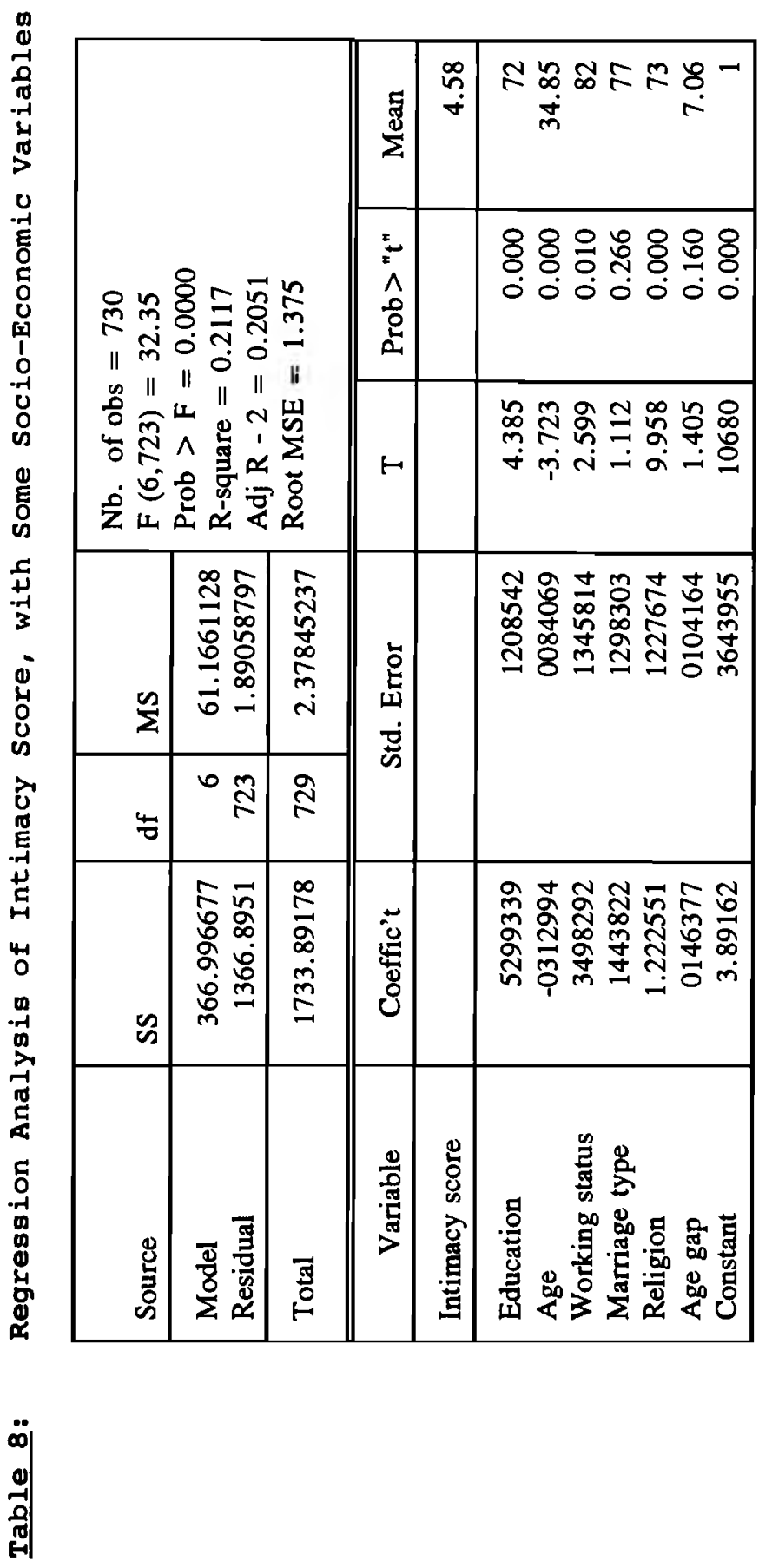


Table 9: Conjugal Deciaion Making Pattern, by SocioEconomic Characteriatica

\begin{tabular}{|c|c|c|c|c|c|c|}
\hline \multirow[t]{2}{*}{ socio-economic group } & \multicolumn{4}{|c|}{$\begin{array}{c}\text { Decision making } \\
\text { pattern* }\end{array}$} & \multirow{2}{*}{$\begin{array}{l}\text { Number } \\
\text { of } \\
\text { women }\end{array}$} & \multirow{2}{*}{$\begin{array}{l}\mathrm{Chi}^{2} / \\
\text { signifi- } \\
\text { cance }\end{array}$} \\
\hline & A & $B$ & c & $\mathrm{D}$ & & \\
\hline $\begin{array}{l}\text { Woman'g education } \\
\text { None } \\
\text { Primary } \\
\text { Secondary } \\
\text { Post-secondary }\end{array}$ & $\begin{array}{r}19.1 \\
20.0 \\
10.5 \\
5.8 \\
\end{array}$ & $\begin{array}{l}38.2 \\
28.9 \\
23.2 \\
15.7 \\
\end{array}$ & $\begin{array}{l}32.4 \\
35.5 \\
39.0 \\
35.6 \\
\end{array}$ & $\begin{array}{l}10.3 \\
15.6 \\
27.3 \\
42.9 \\
\end{array}$ & $\begin{array}{r}68 \\
135 \\
344 \\
191 \\
\end{array}$ & $\begin{array}{r}61.62 / \\
0.000\end{array}$ \\
\hline $\begin{array}{l}\frac{\text { Reliqion }}{\text { Christian }} \\
\text { Moslem }\end{array}$ & $\begin{array}{r}9.3 \\
19.8 \\
\end{array}$ & $\begin{array}{l}21.9 \\
29.4 \\
\end{array}$ & $\begin{array}{l}38.0 \\
33.3 \\
\end{array}$ & $\begin{array}{l}30.8 \\
17.5 \\
\end{array}$ & $\begin{array}{l}561 \\
177 \\
\end{array}$ & $\begin{array}{l}25.21 \\
0.000\end{array}$ \\
\hline $\begin{array}{l}\text { Emolovment statug } \\
\text { Working } \\
\text { Not working }\end{array}$ & $\begin{array}{l}10.3 \\
19.8 \\
\end{array}$ & $\begin{array}{l}25.7 \\
13.5 \\
\end{array}$ & $\begin{array}{l}36.0 \\
11.2 \\
\end{array}$ & $\begin{array}{l}28.0 \\
26.0 \\
\end{array}$ & $\begin{array}{l}619 \\
119 \\
\end{array}$ & $\begin{array}{l}14.0 / \\
0.000\end{array}$ \\
\hline $\begin{array}{l}\text { Age aroup } \\
25 \text { years } \\
25-34 \\
35-44 \\
45+\end{array}$ & $\begin{array}{r}15.0 \\
9.3 \\
14.3 \\
9.9 \\
\end{array}$ & $\begin{array}{l}25.0 \\
24.2 \\
23.8 \\
18.0 \\
\end{array}$ & $\begin{array}{l}15.0 \\
37.6 \\
36.3 \\
32.8 \\
\end{array}$ & $\begin{array}{l}15.0 \\
28.9 \\
25.6 \\
39.3 \\
\end{array}$ & $\begin{array}{r}20 \\
322 \\
328 \\
61 \\
\end{array}$ & $\begin{array}{r}10.21 / \\
0.333\end{array}$ \\
\hline $\begin{array}{l}\text { Age difference } \\
<5 \text { years } \\
5-9 \text { years } \\
10+\end{array}$ & $\begin{array}{r}9.3 \\
11.6 \\
16.4 \\
\end{array}$ & $\begin{array}{l}17.8 \\
23.8 \\
28.5 \\
\end{array}$ & $\begin{array}{l}13.1 \\
35.4 \\
31.5 \\
\end{array}$ & $\begin{array}{l}29.8 \\
29.2 \\
23.6 \\
\end{array}$ & $\begin{array}{l}225 \\
311 \\
165 \\
\end{array}$ & $\begin{array}{l}14.3 / \\
0.026\end{array}$ \\
\hline $\begin{array}{l}\text { Husband's education } \\
\text { Primary or less } \\
\text { Secondary or more }\end{array}$ & $\begin{array}{r}23.1 \\
9.6 \\
\end{array}$ & $\begin{array}{l}29.2 \\
22.3\end{array}$ & $\begin{array}{l}30.8 \\
38.0\end{array}$ & $\begin{array}{l}16.9 \\
30.1 \\
\end{array}$ & $\begin{array}{l}130 \\
597\end{array}$ & $\begin{array}{r}26.77 / \\
0.000\end{array}$ \\
\hline
\end{tabular}

* A: Autocratic; B: Incipient democracy; C: Transitional;

D: Egalitarian 


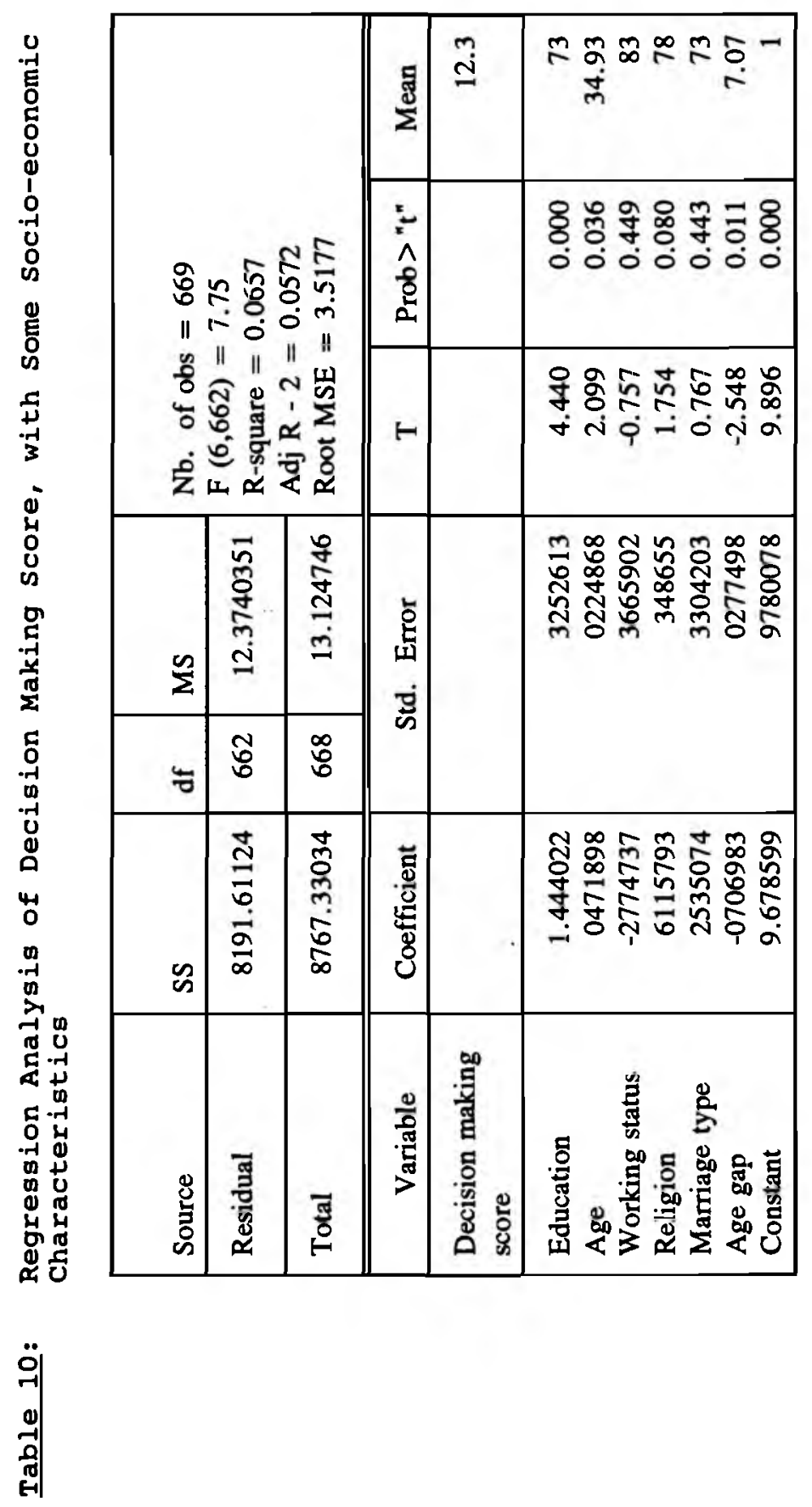




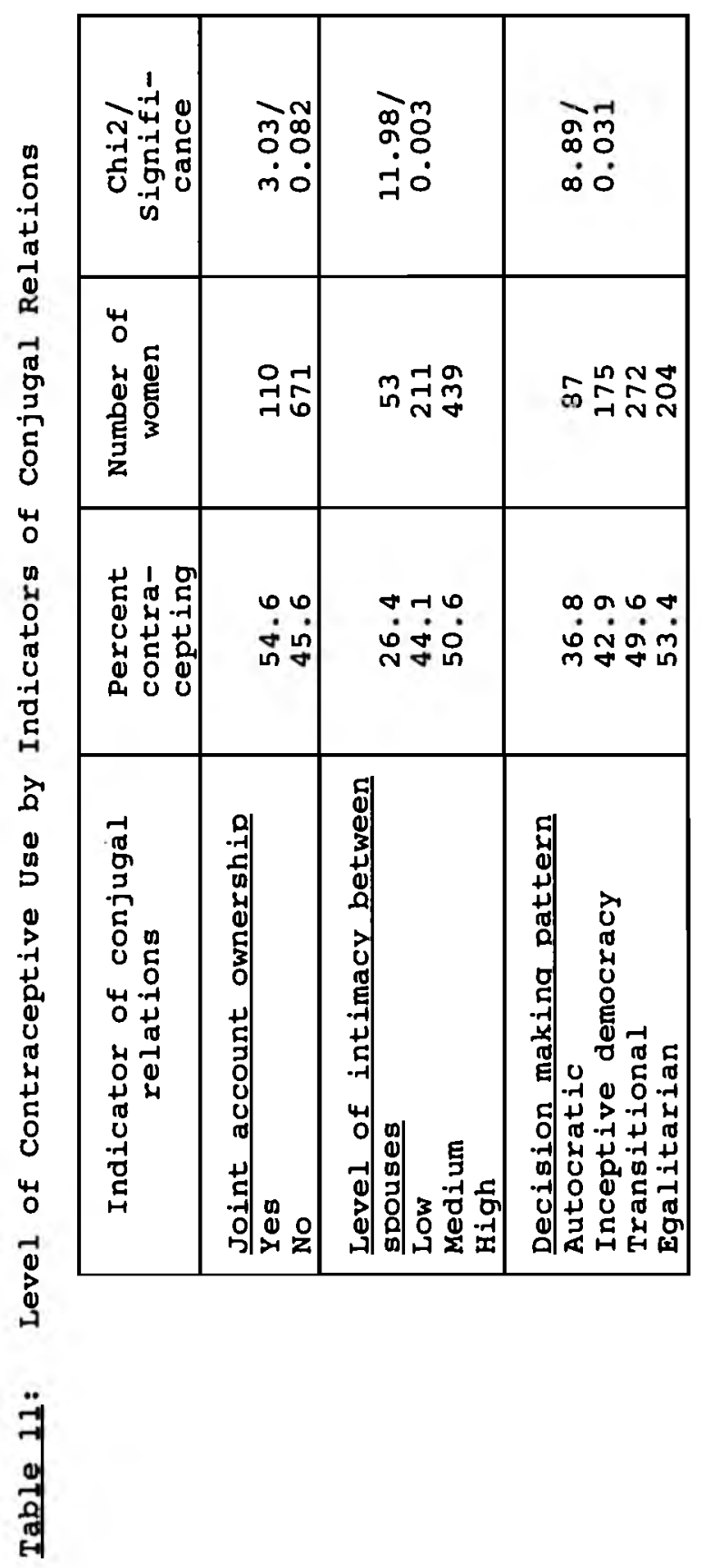




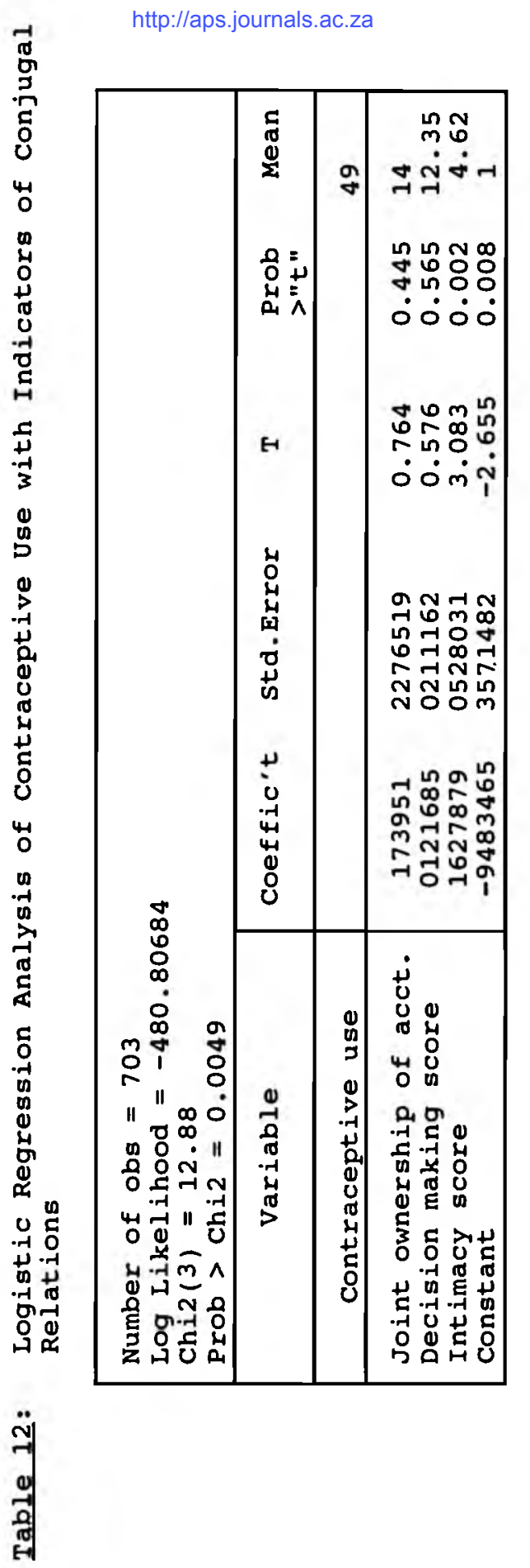


Table 13: Logistic regression of the effects of socioeconomic variables (Model 1), socio-economic factors and conjugal intimacy (Model 2), and combination of socio-economic and conjugal relations factors (Model 3 ), on contraceptive use

\begin{tabular}{|c|c|c|c|}
\hline \multirow{2}{*}{ Independent variable } & \multicolumn{3}{|c|}{ Logic Coefficients } \\
\hline & Model 1 & Model 2 & Model 3 \\
\hline Education & $.5153 * \star$ & $.4362 \star$ & $.419 \star$ \\
\hline Marriage type & $.7179 \star \star \star$ & $.5202 \star \star$ & $.4847 \star$ \\
\hline Religion & .4847 * & $.4687 \star$ & $.5702 \star \star$ \\
\hline Working status & .1761 n.s. & .1149 n.s. & .0611 n.s. \\
\hline Current age & $-.0362 \star$ & $-.0347 \star$ & $-.0334 \star$ \\
\hline Parity & $.264 \star \star \star$ & $.2875 \star \star \star$ & $.2844 \star \star \star *$ \\
\hline Intimacy score & & $.1773 \star \star$ & $.1311 \star$ \\
\hline $\begin{array}{l}\text { Joint financial } \\
\text { management }\end{array}$ & & & .1027 n.s. \\
\hline Decision making score & & & $.005 \ln . \mathbf{s}$ \\
\hline-2 Log-likelihood & 913 & 903.4 & 838.6 \\
\hline Nb. of observations & 703 & 703 & 650 \\
\hline
\end{tabular}

$\begin{array}{ll}* * * & \text { significant at } 0.001 \text { level } \\ * * & \text { significant at } 0.01 \text { level } \\ \text { * } & \text { significant at } 0.05 \text { level } \\ \text { n.a. not significant. }\end{array}$




\section{REFERENCES}

Babalola, S.O. (1992). The Effects of Urbanization on Fertility in South-West Nigeria: the Explanatory Role of the Proximate Fertility Variables. Dakar, Sénégal: UAPS Small Grants Programme on Population and Development, Study Report Number 3 (September).

Back, K.W. and Hass, P.H. (1973). "Family Structure and Fertility Control," Pp. 77-105 in Fawcett, J.T., ed., Psychological Perspective on Population. New York: Basic Books.

Bardsley, P.E. (1983). "The Role of Conjugal Power in the Fertility Decision Making Process," Unpublished doctoral dissertation, University of California, Los Angeles.

Bravo, R. (1989). "Mujer, desarrollo y poblacion en America Latina," Notas de Población 28(48): 35-59.

Davis, K. and Blake, J. (1956). "Social Structure and Fertility: an Analytic Framework," Economic Development and Cultural Change 4:211-35.

Desai, A.N. (1974). "Family Structure and Fertility: A Note on Urban Fertility Patterns," Social Action 24:325-330.

Federal Office of Statistics (1992). Nigeria Demographic and Health Survey 1990. Lagos.

Kar, S. and Cumberland W. (1984). "Impacts of Behavioural Intentions, Social Support, and Accessibility on Contraception: A Cross-Cultural Study," Population and Environment 7(1):17-31. 
Oppong, C. (1977). "Family Type and Size: Some Recent Evidence from Ghana." Pp. 345-354 in Ruzicka, L.T., ed., The Economic and Social Supports for High Fertility: Proceedings of the Conference held in Canberra. 16-18 Nov. 1976. Canberra: Australian National University.

Oppong, C. (1978). "Property, Power and Time: A Reassessment of Ghanaian Student Norms." Pp. 60-74 in Oppong, C. et al., eds., Marriage. Fertility and Parenthood in West Africa. Canberra: Australia National University. 